\title{
THE DEFECTIVE PRICING LAW AND IMPLEMENTING REGULATIONS-A YEAR AND A HALF LATER
}

\author{
WALTER F. PETTIT*
}

On December I, Ig62, the Department of Defense (DOD) and the National Aeronautics and Space Administration (NASA) issued new defective pricing regulations. ${ }^{1}$ The impetus behind these regulations was Public Law 87-653, an act of Congress passed on September 10, $1962 .{ }^{2}$

The issuance of these new regulations immediately touched off a storm of criticism in the government contracting community, a storm which can be likened to the intense controversy which in recent years has centered about the government's patent and proprietary data regulations. At the time of this writing, a year and a half later, only a few of the basic problems have been resolved-and the storm rages on.

It is the purpose of this article to first examine the law and implementing regulations; second, to discuss the manifold problems which have been generated; and third, to suggest certain avenues of relief which may, over a period of time, make the new regulations more palatable to government contractors.

Basic Objectives of the Law and Regulatrons

The basic objective of the Congress in enacting the law, and the Department of Defense and NASA in issuing their regulations, was to give the government

*A.B. I94r, Princeton University; LL.B. 1950, University of California; member of the firm of Allan, Miller, Groezinger, Keesling, \& Martin, San Francisco, California; member of the California bar.

${ }^{x}$ The new Department of Defense (DOD) regulations were set forth in Revision No. 14 to the Armed Services Procurement Regulation (ASPR), while the NASA regulations were published in its Circular No. 257.

${ }^{2} 76$ Stat. 528 (1962). This statute added a new paragraph, ro U.S.C. $\$ 2306(f)$ (Supp. IV, Ig63), to the Armed Services Procurement Act of $x 947$. Congressional action, which led to the passing of Public Law 87-653, was in large part stimulated by impressive reports submitted to Congress by the General Accounting Office (GAO) and by the testimony of GAO representatives before the House and Senate Committees on Armed Services. See Comp. Gen. B-132942, submitted in two reports, one dated May 29, I959 and a second dated July 14, 1959; Hearings Before the Senate Comm. on Armed Services on H.R. 5532, 87th Cong., 2d Sess. 6r-66 (r962) [hereinafter cited as Senate Hearings]. These reports, and the testimony of GAO representatives, furnished considerable evidence to the Congress of (I) defective pricing data in negotiated procurements between the government and industry, and (2) continued failure to require submission, and certification, of pricing data in many non-competitive procurements, despite provision therefor in the then current ASPR. In regard to the former, it was shown, for example, that in the GAO's examination of 218 incentive contracts, amounting to over 8.8 billion dollars, the contractors had exceeded their target estimate in only two instances, one involving an overrun of $\$ 87,000$ and the other an overrun of $\$ 54,000$. "I hardly call that a record of risk taken by the contractors," commented Carl Vinson, Chairman of the House Committee on' Armed Services (Senale Hearings $\mathrm{r}_{7}$ ). As to the latter, the government's failure to require submission of pricing data, the 
additional procedures and provisions for assuring itself that prices negotiated with government contractors in non-competitive procurements would be "fair and

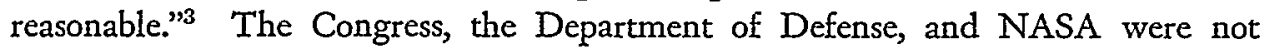
concerned with competitive procurements, since the competitive forces of the market place generally assure the government that the prices it is paying are reasonable.

To achieve this basic objective, "fair and reasonable prices" in non-competitive procurement, the law and regulations require ( $I$ ) more extensive use of cost and price analyses and (2) certification by contractors, when cost or price data is submitted, that such data is complete, accurate and current. Oddly enough, the primary motivation behind the law, as evidenced by hearings before the United States Senate, was congressional concern over the lack of complete, accurate and current pricing data in the government's dealings with industry. "Truth in negotiating," it was declared, was needed. 5 Since enactment of the law, however, the interest and concern of all parties have shifted from "truth in negotiating" to the government's demand for more extensive use of cost and price analyses.

\section{II}

\section{Department of Defense Regulations}

The Department of Defense regulations ${ }^{6}$ require government contractors and subcontractors to submit cost or pricing data, and to certify that, to the best

GAO revealed that of $36_{4}$ prime contracts entered into since the defective pricing regulations were first adopted in October of 1959, I2I of them, having a total value of 253 million dollars, had no certified cost data as required by the regulations (Sente Hearings 66 ).

${ }^{B}$ ASPR 3 -80I.I, 32 C.F.R. $\$ 3.801-1$ (1963).

Senate Hearings $\mathrm{I} 6,22,34,6 \mathrm{r}$, and 62 .

¿ Senate Committee on Armed Services, S. REP. No. $188_{4}, 87$ th Cong., 2d Sess. 4 (1962).

${ }^{\circ}$ ASPR $3-807.3,32$ C.F.R. $\$ 3.807-3$ (I963). See also NASA PR $3.807-3$, which are the defective pricing regulations applicable to NASA procurements. NASA regulations aro not set forth hercin, nor discussed, since they parallel for the most part the provisions of Public Law $87-653$ and, being less arduous than the ASPR regulations, have not caused as much difficulty.

For historical reasons, it is interesting to note here that the DOD defective pricing regulations, dated December I, I962, were not the first regulations to be published on this subject. As early as October 1959, at the urging of the Congress and the GAO, the DOD adopted comprehensive defective pricing regulations. These regulations were revised several times, the latest, prior to the enactment of Public Law 87-653, being those dated January 3I, 1961. The regulations of December 1,1962 (in this article referred to as the "new regulations") were far tougher and more detailed than the regulations which preceded congressional action in the summer of 1962 , and they differed in the following respects from the earlier versions.

I. The new regulations were made applicable to more prime contracts and more subcontracts.

2. The "catalog or market price" exception for negotiated fixed-price contracts over $\$ 100,000$, was qualified to such a degree by the new regulations that it has been far more difficult, since then, for a contractor or a subcontractor to bring himself within this exception.

3. The earlier regulations merely required the contractor, during price negotiations, to "diselose any significant and reasonable cost or pricing data." The new regulations omitted this terminology. This omission has raised this question: Suppose the data in the contractor's opinion is insignificant or is not reasonably available. If such data is not furnished (because it is insignificant or not reasonably available) does the contractor under the new regulations violate his certificate? The answer is not clear, and the problems which flow from this uncertainty are discussed hereinafter in the text.

4. The old clause provided for an "equitable adjustment" in the event that the price data submitted was defective. The new regulations, on the other hand, when issued, provided, and still do, that the price shall be "reduced accordingly." This change in language has brought about considerable un- 
of their knowledge and belief, the data submitted is accurate, complete, and current, prior to:

I. the award of any cost-reimbursement type, incentive, or price redeterminable contract, regardless of the dollar amount;

2. the award of any firm fixed-price or fixed-price with escalation negotiated contract expected to exceed \$100,000 in amount;

3. any contract modification expected to exceed $\$ 100,000$ in amount to any formally advertised or negotiated contract whether or not cost or pricing data was required in connection with the initial pricing of the contract; and

4. the award of any negotiated contract not expected to exceed \$100,000 in amount or any contract modification not expected to exceed $\$ 100,000$ in amount to any formally advertised or negotiated contract whether or not cost or pricing data was required in connection with the initial pricing of the contract, provided the contracting officer considers that the circumstances warrant such action.

unless, in the case of paragraphs 2,3 , and 4 above, the price negotiated is based on adequate price competition, established catalog or market prices of commercial items sold in substantial quantities to the general public, or prices set by law or regulation. The requirements set forth in paragraphs $I, 2$, and 3 above, may be waived in exceptional cases where the Secretary of the department involved authorizes such waiver and states in writing his reasons therefor.

Whenever certification of cost or pricing data is required, the regulations further provide that the price reduction clause set forth in Armed Services Procurement Regulation (ASPR) 7-104.29 $9^{7}$ be included in the contract, together with applicable audit and subcontract clauses, found in ASPR 7-104.41 ${ }^{8}$ and 7-104.42. ${ }^{\circ}$

Some observations should be made here in respect to the ASPR clauses and the certificate to be signed by contractors and subcontractors.

First, in regard to ASPR 7-r04.29, the price reduction clause, it should be noted that this is in essence a recapture provision which enables the government to recoup excessive prices to the extent that such prices are based upon defective data. The amount involved must be "significant." What constitutes a "significant" sum, however, has yet to be defined by a court or administrative board. ${ }^{10}$

It should be further noted that the price reduction provided for in this clause

certainty and raised the question as to whether or not the new regulations make a "onc-way street" out of price adjustments under ASPR 7-I04.29, 32 C.F.R. $\$ 7.104 .29$ (I963).

${ }^{7} 32$ C.F.R. $\$ 7.104-29$ ( 1963$)$.

${ }^{8} 32$ C.F.R. $\$ 7.104-41(1963)$.

32 C.F.R. $\$ 7.104-42$ (1963).

${ }^{10}$ Webster's New International Dictionary (2d ed. I939) defines significant, in part, as "r. Having a meaning; esp., full of import; expressive. . . . 3. Deserving to be considered important, momentous." These definitions appear to be the most appropriate descriptions of the term as it is used in the price reduction clause. Probably the single word "important" is closest in meaning. No reported cases have defined this word in the context of significant sum or amount. It is regrettable that some other word was not used by the ASPR Committee in drafting the price reduction clause, some word such as "substantial," since this word has frequently been interpreted by the courts in connection with sums of money and values. Atchison T. \& S. F. Ry. Co. v. Kings County Water Dist., 47 Cal. 2d I40, 302 P.2d I, 3 (I956); Lord v. Pahl, 254 Minn. 349, 95 N.W.2d 85, 89 (1959); Application of Scroggin, I03 Cal. App. 2d 28I, 229 P.2d 489, 49I (I95I); Estate of Teed, Ir2 Cal. App. 2d 638, 247 P.2d 54, 58 (1952). 
is not an "equitable adjustment" downward. The price must be reduced to the extent that it is determined to be inaccurate, incomplete, or non-current. This language would seem to exclude from consideration such equities as a contractor's reduction in profit or loss due to his own incorrect cost or pricing data. In other words, it would appear that this clause can reasonably be interpreted as a "one-way street."

Second, in respect to ASPR 7-I04.4I, which sets forth appropriate audit provisions, it should be observed that this regulation includes two types of clauses. The first, simply referred to as "Audit," is the clause to be used in negotiated fixed-price contracts, exceeding $\$ 100,000$. This clause restricts the contracting officer's audit to the accuracy, completeness and currency of the cost or pricing data submitted to the government at the time of, and for the purpose of, entering into the contract. It does not permit an audit of performance costs. Some contracting officers have sought performance costs (which are not actually relevant) through the use of the examination of records clause. ${ }^{11}$ This clause, however, is for the use of the Comptroller General and not the contracting officer, and such indirect attempts to audit performance costs in fixed-price contracts are not proper.

The other type of audit clause included in ASPR 7-I04-4I is designated "Audit and Records." It is to be used in connection with cost-reimbursement type, incentive and price redeterminable contracts. Here the right to audit performance costs is accorded to the contracting officer and is necessary for purposes other than defective pricing.

Third, in regard to ASPR 7-I04.42, it will be seen that this clause deals with provisions to be inserted in subcontracts. The use of these clauses, and the obligations of subcontractors thereunder, has run afoul of much uncertainty and confusion. This problem is dealt with at some length below. Suffice it here to note (I) that these subcontract clauses are only to be used when the prime contract itself contains defective pricing clauses, and (2) that they must be inserted, when required, in order to preserve for the prime contractor a right to recapture excessive defective prices.

Fourth, let us consider the criminal penalties referenced on the certificate. This reference gives notice to the contractor or subcontractor that he is subject to criminal penalties for making false representations to the government by virtue of section roor, I8 U.S. Code. ${ }^{12}$ To prosecute under this statute, the government must show that the contractor intentionally submitted inaccurate, incomplete, or non-current cost or pricing data. An honest mistake, by the language of the certificate and under the general law, is not subject to criminal prosecution. If by chance this notice were omitted from the certificate, either by the government or by a prime contractor, the statute in all probability would still be applicable. It should be noted, too, that this statute is applicable to subcontractors as well as to prime contractors. ${ }^{13}$

${ }^{11}$ ASPR 7-104.15, 32 C.F.R. $\$$ 7.104-15 (x963).

${ }^{12} 62$ Stat. 749 (1948), I8 U.S.C. \$ Ioor (I958).

${ }^{10}$ United States v. Steiner Plastics, 23I F.2d 149 (2d Cir. 1956). 


\section{III}

Is DOD's Implementation Beyond the Scope and Authority of the Statute?

The contention has been made that the Department of Defense, in implementing Public Law 87-653, extended the regulations far beyond the scope, authority, and intent of the statute and that, to the extent that this has been done, the regulations are without statutory authority and are accordingly bereft of the force of law.

The regulations, of course, have made extensive additions to the statutory requirements. It was necessary, for example, to add audit provisions (without which the basic intent of the statute could not have been carried out), a price reduction clause, and subcontract provisions, and to provide in the regulations guidance for the use of these clauses. There has been some dispute concerning the language used in the referenced clauses but no dispute has been raised as to the authority of the Department of Defense to include these clauses in the regulations.

One change in the statute, however, has drawn considerable fire-namely, the provision permitting the contracting officer to request cost or pricing data in fixedprice contracts under $\$ 100,000$, if in his opinion the request for such data is warranted. It has been claimed that this provision is inconsistent with the \$roo,000 "floor" set forth in the law and is therefore improper.

From a legal standpoint, it would be most difficult for a contractor to prevail in this contention. First, unless such a discretion under $\$ 100,000$ is specifically prohibited by the statute, the Department of Defense would pretty clearly have the right to issue such a provision. In the recent case of G. L. Christian \& Associates $v$. United States, ${ }^{14}$ a decision quite famous on other points, the Court of Claims said:

Unless the Congress has prohibited the agency from entering some phase of the contractual process (or using some otherwise lawful method of contracting), a grant of wide and general authority to contract and procure will extend to all reasonable phases and methods.

Since there is no prohibition against requesting cost or price data for contracts under $\$$ 100,000, it can probably be concluded that the Department of Defense has not exceeded its powers (in view of the broad rights accorded to the service departments under the Armed Services Procurement Act of 1947)..$^{15}$ Moreover, the statute can probably be reasonably interpreted as making pricing data mandatory over $\$ 100,000$ (if all other conditions are met) and non-mandatory or discretionary under \$100,000.

The government, a prime contractor, or any buyer, furthermore, has the prerogative of setting the terms and conditions pursuant to which it will make its purchases.

\footnotetext{
${ }^{14} 320$ F.2d 345,348 (Ct. Cl. I963), cert. denied, 375 U.S. 954 (1963), petition for rehearing denied, 376 U.S. 929 (1964). To the same effect, and cited in the Christian decision, are the following cases: Kern-Limerick, Inc. v. Scurlock, 347 U.S. Iro, $\mathrm{II}_{4}$ ff. (1954); Public Utilities Commission of California v. United States, 355 U.S. 534, 540-43 (I958); Paul v. United States, 37 I U.S. 245, 251-55, 261-363 (1963); United States v. Penn Foundry \& Mfg. Co., Inc., 337 U.S. 198, 214-16 (1949) (opinion of Mr. Justice Douglas).

${ }^{16} 62$ Stat. 21 (1948), as amended, ro U.S.C. $\$ \$ 2301-I_{4}$ (1958).
} 
If the government, for example, were to refuse to negotiate or enter into a contract unless it first received cost or price data, the potential contractor would find it extremely difficult to contest this decision. ${ }^{16}$ And this is true, even though there was in fact "adequate price competition" or qualifying "catalog or market prices," or even if the contracting officer had in some other respect acted contrary to the policies set forth in ASPR or other departmental regulations. The contractor's only recourse would be to (I) refuse to sell to the government on its basis (a powerful weapon in non-competitive procurement, particularly if the contractor is in fact "sole source"), or (2) appeal to higher authority within the department involved for a reversal or qualification of the terms set by the contracting officer.

Neither of the above approaches, however, would be effective if the contracting officer was required by Public Law 87-653 or some mandatory departmental regulation to set the terms accordingly-that is, to require a cost or price breakdown under the particular circumstances. It would only be in the area in which the contracting officer has discretion, as in negotiated fixed-price contracts under $\$$ roo,ooo, or in determining whether or not there had in fact been "adequate price competition," that the contractor's refusal to sell to the government, or appeal to higher authority, might result in a change in the requirements.

\section{IV}

\section{Why Contractors Resist Furnishing Cost Data}

Since enactment of the law and publication of the regulations, there has been, as noted above, a decided shift in the "87-653" storm center-a shift from an interest in the "truth in negotiating" requirements, as contained in the statute and regulations, to a deep concern over the government's extensive demand for submission of cost data.

This shift can be attributed in large part to an increasing acceptance of the fact that, when dealing with the government and the expenditure of public funds, government contractors and subcontractors can no longer rely on the doctrine of caveat emptor. In other words, when cost data is required, it is generally accepted that such data must be accurate, complete, and current. On the other hand, the government contract industry cannot accept, and in fact strongly resists, the government's growing demand for submission of certified cost data. In brief, here are the reasons why.

\section{A. Invasion of Privacy}

First, the submission of cost data in a fixed-price procurement is viewed as an invasion of privacy. Detailed cost information, many contractors argue, is often

${ }^{10}$ Although bid and award problems may be litigated in court, Noce v. Edward E. Morgan Co., ro6 F.2d 746 (8th Cir. I939), a bidder ordinarily cannot compel an award to him, or prevent an award to another bidder, or recover damages for failure to follow discretionary regulations. See United States v. Gray Line Water Tours of Charleston, 3II F.2d 779 (4th Cir. I962); and Heyer Products Co. v. United States, 140 F. Supp. 409 (Ct. Cl. 1956). 
of a proprietary nature and is guarded by a company as assiduously as is any other trade secret. A disclosure, it is said, might well result in an impairment of a company's competitive position or in some cases an undermining of its very existence.

Such concern is undoubtedly justified, for instance, where a subcontractor is required to furnish cost data to its prime, particularly if its prime is a competitor. The suggestion that this information can be given to the government, and not to the prime, does not appear to improve the situation. Such data, once given, is difficult to control, and, should it fall into the hands of others, inadvertently or otherwise, there is no legal recourse against the government or any other party.

There is a tendency in government circles to minimize this ground, government officials contending that contractors who deal with the government live in "glass bowls" and that today full and complete disclosure is the accepted way of doing business with the government. Where multi-million dollar contracts are involved, there is obvious validity in this contention. Where, however, the contracts involved are small, fixed-price, and call for furnishing proprietary products, a company's desire to guard its cost and price information is quite understandable.

\section{B. Administrative Burden}

Second, the furnishing of cost data, it is claimed, generally increases a company's administrative burden. Contractors argue that, in some cases, it means added administrative, accounting, and legal personnel to insure proper compliance-not only at the prime level but also in the administration of subcontracts. In other cases, it is said, a complete change in a company's accounting system and pricing policies may be required.

Undoubtedly, there is an added burden. The question, however, is: Who bears the burden, the government or industry? There can be little doubt that in most cases the added costs will be passed on to the government. Whether or not these additional costs "net out" in favor of the government is not our concern here. We are solely interested in whether or not contractors are substantially prejudiced by this additional burden.

Conceivably, contractors having a strong proprietary line of products (and thus frequently being required to furnish cost data and assume associated administrative burdens) could find themselves at a disadvantage if required to compete with contractors primarily engaged in competitive procurements, for the latter would for the most part escape such administrative costs. Aside from this type of situation, however, the added administrative burden involved in submitting the cost data should not work a substantial hardship on most contractors.

\section{Subcontract Problems}

Third, contractors express great concern over the administrative difficulties and potential liability involved in the subcontract clauses and procedures required by 
the regulations-which necessarily accompany the submission of certified cost data. ${ }^{17}$ After careful study of the problem, the legal department of one large government contractor made the following observation: $:^{18}$

The choice of the correct clauses for any particular subcontract, depending upon the type and dollar amount of the prime contract under which it is issued and the type and dollar amount of the subcontract itself, is extremely complicated. More than 50 prime contractsubcontract situations involving the application of 9 principal prime contract clauses and 13 principal subcontract clauses are involved.

In addition thereto, contractors point to the tough problems encountered in trying to convince subcontractors with proprietary products that certified cost data must be submitted and to the subsequent task they face with the government when such subcontractors cannot be so persuaded.

Unquestionably there exist difficulties and burdens such as these; but like other administrative burdens, referred to above, the cost thereof can usually be passed on to the government, and with a little experience most contractors should be able to find some practical solution to these subcontract dilemmas. ${ }^{19}$

The real problem presented to contractors by the use of the required subcontract procedures is the contingent liability to which the prime is thereby exposed. Under ASPR $3-807.5(b),{ }^{20}$ for example, if cost data and a certificate "should have been furnished" by a subcontractor, and they were not, either because the prime contractor incorrectly believed there to be "adequate price competition" or a qualifying catalog or market price, and if it is subsequently determined that the subcontractor's price was defective, then the prime contractor is liable for the price reduction and may well have no recourse against the subcontractor. Moreover, if a subcontractor becomes bankrupt, a prime probably would be unable to enforce his price reduction rights. And the prime, as the regulations now stand, would then be fully liable. One further point. If a subcontractor furnishes his cost data only to the government (which might occur because of competitive conditions), the prime might not have available to him the necessary evidence to support a claim for price reduction.

All considered, it would seem that contractors are justified in resisting the submission of certified cost data due to the substantial contingent liabilities which are imposed by the required subcontract clauses and procedures. To remedy this situation, and to accord prime contractors protection in this area, the regulations should be changed.

\footnotetext{
${ }^{27}$ For a thorough analysis of the manifold problems created for primes and subcontractors subject to "87-653," see "Prime and Subcontract Relationships," an address by Frederick Sass, Jr., Counsel, Bureau of Naval Weapons, Department of the Navy, before the Southwestern Legal Foundation, Nov. 15, 1963.

${ }^{28}$ Paper entitled "Prime and Subcontract Requirements Regarding Cost Data, Certification of Cost Data, Audit and Price Adjustments as Required by Public Law $87-653$ and the ASPR" prepared by the Legal Department, Hercules Powder Company, July 31 , 1963.

${ }^{10}$ Ibid.

${ }^{20} 32$ C.F.R. $\$ 3.807-5$ (b) $(1963)$.
} 


\section{Uncertainty in Terms}

Fourth, all contractors are concerned with the uncertainty created by many of the terms used in the regulations. How complete, accurate, and current, they ask, must a contractor's figures be? What standards will be applied? Does the requirement for accuracy, completeness, and currency apply to estimates or just to historical costs?21 In administering subcontracts, what guidelines should be applied in determining whether or not there exists "adequate price competition" and "established catalog or market prices"? Are "honest mistakes" subject to a price reduction?

Few will disagree that there is indeed a lack of clarity in the regulations. Better definitions, which will undoubtedly be developed by the ASPR Committee of the Department of Defense and by decisions of administrative boards and the courts, will dispel most of this uncertainty. Until such time, however, there seems to be ample justification for resisting the submission of certified cost data on this ground.

Before turning to the next ground, let us briefly consider the uncertainty involved in whether or not an "honest mistake" (under the statute and regulations) is subject to a price reduction. The importance of this problem deserves additional comment.

Apparently, the Department of Defense takes the position that defective prices brought about by an "honest mistake" must be adjusted in the same manner and to the same extent as if the defect had been intentional. ${ }^{22}$ This position seems to be in accord with that of the General Accounting Office ${ }^{23}$ and is based on the alleged unacceptability of permitting a contractor to retain a "windfall profit." This interpretation, the Department of Defense asserts, is in line with the language of the clause and the intent of Congress. ${ }^{24}$

On technical grounds, it is difficult to agree with the Department of Defense. The price reduction clause clearly provides ${ }^{25}$ that a reduction will be made if the data furnished was not complete, accurate, and current "as certified" in the contractor's certificate. And the contractor's certification clearly exempts "honest mistakes." Nor is the government's interpretation uniformly supported by congressional intent. While there is some indication that certain members of Congress, during hearings on Public Law $87-653$, believed that "honest mistakes" should be subject to price adjustment, ${ }^{26}$ there is an equally strong indication that other members believed that a contractor should be responsible for only those defects in pricing of which he had knowledge. For example, Congressman Edwin Hebert, the author of the bill

${ }^{21}$ Department of the Army, Circular No. 715-2-27, Oct. 18, 1963, Paragraph D. "Ccrtification of Cost and Pricing Data," in part provides: "The certification does not make any representations as to the accuracy of cost projections and, hence of proposed prices of work to be done in the future."

${ }^{22}$ Department of Defense paper entitled "Defense Contract Pricing and Public Law 87.653," dated Aug. 15, 1963, page 2, submitted to the Honorable Clair Engle, United States Senate, on Aug. 26, 1963. See also, comments by the DOD on H.R. 7909, 88th Cong., 2d Sess. (1964).

${ }^{23}$ Senate Hearings 62.

${ }^{24}$ Department of Defense memorandum, supra note 22, at 2.

${ }^{25}$ ASPR 7-104.29, 32 C.F.R. \$ 7.104-29 (I963).

${ }^{20}$ Senate Hearings ror and ro2. But in contrast thereto, see id. at 99. 
stated:"27 "All this section requires is that the truth be made known at the time of the bargaining. Who can object to telling the truth? The argument about persons being penalized for what they do not know is plain nonsense."

Far more important than technical reasons, however, is the basic inequity in requiring a contractor to forego a "windfall profit" while asking him at the same time to assume and absorb a "windfall loss." For example, if a contractor experiences a substantial loss due to inaccurate pricing information (e.g., misplacement of a decimal point), that is "his baby," his problem, according to the Department of Defense interpretation, and the free enterprise system magnificently prevails. If, however, a similar mistake yields him unanticipated profit, and it was an "honest mistake," the contractor must then, under the Department of Defense view, relinquish his good fortune and confer the benefits upon the government. In this case apparently, free enterprise has no application.

Not to be forgotten in the discussion of equities, is the protection afforded to the government by way of the Renegotiation Act. ${ }^{28}$ Here there is no "reduction accordingly" 20 for an extra benefit brought about by an "honest mistake." Rather there is a balancing of the many factors involved, including "windfall losses," if any, and the contractor is generally granted an overall reasonable profit.

At the very least, it can be concluded, the concept of "windfall profits" should be re-examined by the Congress and the Department of Defense, particularly in light of the effect of "windfall losses," and clarifying regulations should thereafter be issued in accordance with the findings. ${ }^{30}$

\section{E. The Problem in Obtaining "Fair and Reasonable Prices"}

Fifth, and of major concern to contractors who develop a proprietary product line with their own funds and attempt to sell it to the government or other customers, is the contractor's ever increasing problem of negotiating a "fair and reasonable price," ${ }^{\text {"31 }}$ when cost data is submitted.

Under the "rules of the game," as it is presently played, there is an insufficient profit, these contractors claim, to cover product development costs, contingencies implicit in a "proprietary product" business, and other "unallowable" costs, if at the same time a fair return to the contractor's stockholders is to be provided. And this is true, it is further maintained, even under the new weighted profit guidelines. ${ }^{32}$

There can be little doubt that there has been in the past ten or fifteen years a gradual erosion of "allowable" costs, when contracts are negotiated or administered in accordance with the provisions of ASPR section fifteen. The usual justification for this erosion is (I) that such costs are not properly chargeable to government

${ }^{27}$ Senate Hearings 57 .

${ }^{38} 65$ Stat. 7 (I95I), as amended, 50 U.S.C. App. $§$ I2II-33 (I958).

${ }^{30}$ ASPR 7-104.29, 32 C.F.R. \$ 7.104-29 (1963).

${ }^{30}$ H.R. 7909, 88th Cong., 2d Sess. (1964), a bill sponsored by Representative Edwin Hebert (D. La.), seeks to make it clear that "honest mistakes" are not subject to price reduction.

${ }^{32}$ ASPR 3-80I.r, 32 C.F.R. $\$ 3.801-1$ (1963).

${ }^{32}$ ASPR $3-808.2,32$ C.F.R. $\$ 3.808-2$ (I963). 
work, even though "a cost of doing business," or (2) that such costs can and should be recouped from profit. This rationalization, however, disregards "the fact of life" that in practice anything more than a modest profit, ranging somewhere in the neighborhood of plus or minus ten per cent on fixed-price jobs, is unacceptable, and that such profits, particularly where "proprietary product" contractors are involved, can be, and often are, insufficient to carry the load of "unallowable" costs.

This problem is compounded, moreover, by a rigid adherence "in the field" to the use of ASPR Section XV cost principles in negotiating fixed-price contracts, despite regulations and directives giving contracting officers considerable leeway to exercise business judgment. Then, too, practice and policies often vary widely from one department, bureau, command, activity, and so forth, to the next.

What then is needed? Generally speaking, there should be a recognition that "fair and reasonable prices" is a double-edged sword. To insure fairness, the price negotiated must be just to both parties. A starting point certainly would be a review of the allowability of product development costs and contingencies frequently encountered by "high risk" Research and Development (R\&D) contractors. Many government representatives contend that there is presently sufficient justification for the allowability of such costs in the regulations- to the extent, of course, permitted. However, it must be concluded that there is a lack of clarity; otherwise interpretations as to what is allowed by ASPR would not vary so greatly. If costs of this nature were to be realistically placed in the "cost" column, then profit standards provided by the new weighted guidelines would, if properly applied, undoubtedly result in a fair return to most contractors.

"Four Escapes" from the Submission of Cost Data

Based on the foregoing discussion, it would be hard to dispute the fact that most contractors are justified in resisting the submission of certified cost data. As the law and regulations presently stand, the risks involved in such submissions are considerable.

If this is true, what recourse then is available to contractors who wish to avoid a cost breakdown? Under the regulations, "four escapes" are provided: ${ }^{33}$ (I) a fixedprice contract under $\$ 100,000$ (subject, however, to the contracting officer's discretion); (2) "adequate price competition" for the item to be procured; (3) "established catalog or market prices of commercial items sold in substantial quantities to the general public," similar to the item to be procured; and (4) a submission of price instead of cost data. These "escapes" are easy to state but difficult to define and apply. In fact, for the past year and a half, the "87-653" storm has whirled most tightly around the application of these terms.

Due to this particular controversy, industry groups and the Department of ${ }^{33}$ ASPR 3-807.3, as amended by Defense Procurement Circular No. 3, dated March 4, 1964. 
Defense ASPR Committee have given more attention to the problems involved here than to any other area. And this attention has resulted in considerable clarification and more realistic attitudes than were current at the time the new regulations were first published on December I, I962. The abuses, and "horror" cases, brought about by discretion being given to contracting officers in fixed-price contracts under \$roo,000, have been largely rectified. ${ }^{34}$ Furthermore, the terms "adequate price competition" and "established catalog or market prices" have been better and more completely redefined. ${ }^{35}$

It would serve little purpose here to relate the history of the controversies surrounding these terms. The battle has been hard fought, and the decision of the ASPR Committee now rendered. Most contractors would probably agree that there has been a substantial improvement in the definition of these four "escapes."

\section{ConCLUSION}

From the foregoing discussion, this much is clear: The basic problems created by the " $87-653$ " law and regulations persist. Some improvements have been made, particularly in the definition and applicability of such terms as "adequate price competition," "established catalog or market prices," price data and the under \$100,000 exemption. To make the law and regulations acceptable to industry, however, more improvements are needed-improvements which will provide (I) greater protection to prime contractors for contingent liabilities now imposed upon them, or adequate compensation therefor; (2) more complete explanations and better definitions of the many nebulous terms and concepts contained in the regulations; and (3) more realistic pricing for fixed price, "proprietary product" contractors.

It can also be concluded from the foregoing that all contractors and subcontractors are not equally affected by the law and regulations. Prime contractors are principally concerned with (I) contingent liabilities and the difficult administrative problems created by the necessity of passing down the " $87-653$ " provisions to subcontractors and (2) the administrative burdens involved in providing complete, accurate, and current cost data. These problems are substantial and real. However, the cost of these additional burdens can for the most part be passed on to the government. The primes' profits are not noticeably affected. Small and medium-sized contractors and subcontractors, on the other hand-particularly those who offer a "proprietary product" line-not only have the major prime contractors' problems, but in addition thereto are faced with the even greater burden of unrealistic pricing by the government when cost data is submitted. In effect, in so far as "proprietary product" contractors are concerned, Public Law 87-653 is essentially an "anti-profit" measure.

The most significant step that can be taken by the government at this time to increase the acceptability of " $87-653$ " would be a forthright and complete reappraisal of the government contract industry. For the past several years, the industry has

${ }^{34}$ Ibid.

${ }^{85}$ Ibid. 
been under constant attack for improprieties in pricing and its members have been pictured as "war profiteers," gathering profits by juggling accounts and figures and by misrepresentations. ${ }^{36}$ This image of the industry is unjustified and not factual.

Few can fault the tenacity and competency with which the General Accounting Office (GAO) has sought out and exposed improprieties in pricing government contracts. These improprieties, however, are not commonplace. Few have been intentional and most have been corrected. What is now needed, and badly, is a more balanced, realistic picture of the industry as a whole. The GAO and other responsible agencies and representatives of the government owe an obligation to the nation and to the Congress to present to them a greater perspective of the forces at play in government contracts: declining profits, tremendous risks consciously assumed, everyday "break-throughs" in difficult engineering and scientific problems, unbelievable "on schedule" deliveries of never-before-built products. These events deserve special recognition.

Of particular importance is the profit deterioration being experienced by government contractors. For example, the Renegotiation Board has reported the following profit margins for renegotiable business for the years 1956 through $\mathrm{rg}_{93} 3^{37}$

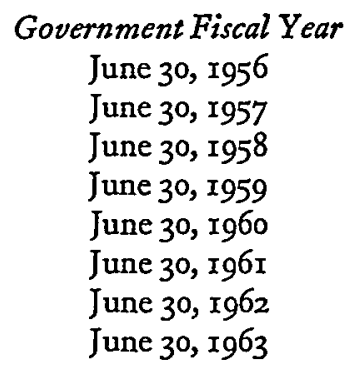

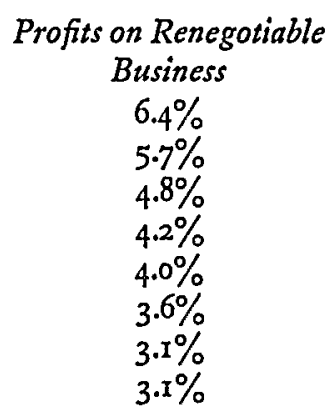

Moreover, the Eighth Annual Report of the Board, published on December 3r, 1963 , disclosed that 1,077 of the 3,487 contractors reviewed, or thirty-one per cent thereof, sustained losses on government contract work. Is this a record of unconscionable pricing, a profit spree, or misuse of public funds? Surely, the time has come to recognize the contributions being made daily by the government contract industry.

Equally as important as the need for a "new look" at government contractors is the necessity of a re-examination of the inequities being injected into government procurement by " $87-653$." It has been noted above how manifestly unfair is the concept of

\footnotetext{
${ }^{88}$ On March 31, 1964, the Senate Permanent Subcommittee on Investigations, under the chairmanship of Senator John J. McClellan, published a report on alleged excessive profits in the government contract industry. Senate Permanent Subcomm. on Investigations, S. Rep. No. 970, 88th Cong., 2d Sess. (rg64). For a thoughtful comment on this report, see 6 Gov't Contractor $q$ r 69 (rg64).

${ }^{87}$ Annual Reports to Congress are made by the Renegotiation Board pursuant to section $\mathrm{II}_{4}$ of the Renegotiation Amendments Act of 1956 . Profit compilations are computed on the basis of data appearing in the first through the eighth such annual reports. The reports are submitted in December. Copies may be obtained from the Superintendent of Documents, U.S. Government Printing Office, Washington, D.C.
} 
the government's recouping "windfall profits," attributable to honest mistakes, while at the same time requiring contractors to assume "windfall losses." Similar to this inequity is the "Heads I win, tails you lose" interpretation of the price adjustment clause, where defective pricing is involved. Here, it is claimed, the government is entitled to a downward adjustment in the price, if the defect increases the price, while the contractor is not entitled to offset or recoup a decrease in price due to a similar defect. Even though the language may justify such an interpretation, the important point is that a strong and vital procurement process cannot long last nor be supported by such obviously unjust procedures and concepts.

With a better understanding of the government contract industry and particularly the overall reasonableness of its prices, and with a greater sense of fairness toward contractors, the still needed improvements in Public Law 87-653 and the regulations should soon follow. 